\title{
Charakter prawny i rola wieloletniej prognozy finansowej w kontekście rosnącego zadłużenia jednostek samorządu terytorialnego
}

\author{
Legal character and role of long-term financial projection \\ in the context of growing liabilities of local government units
}

\begin{abstract}
Streszczenie:
Wieloletnia prognoza finansowa miała stanowić nowoczesny instrument w zarządzaniu finansami samorządowymi, będąc jednocześnie dokumentem oraz aktem prawnym, który umożliwia wydłużenie okresu planowania oraz stabilizację finansową w samorządzie terytorialnym. Celem niniejszego artykułu jest wskazanie, jaką rolę spełnia wieloletnia prognoza finansowa w kontekście rosnącego zadłużenia jednostek samorządu terytorialnego. Jako zalety planowania wieloletniego wymieniono m.in. bardziej racjonalne gospodarowanie środkami publicznymi, zwiększenie wiarygodności, przejrzystości oraz przewidywalności polityki fiskalnej oraz dopasowanie do planowania na szczeblu unijnym. Zadłużenie w samorządzie stanowi bardzo ważny problem, ponieważ przez wiele lat wskaźnik zadłużenia w jednostkach samorządu terytorialnego utrzymywał się na bardzo wysokim poziomie. Obok wskazania roli wieloletniej prognozy finansowej w artykule przedstawiono również kwestie związane z uchwalaniem prognozy finansowej, jednocześnie podkreślając rolę regionalnych izb obrachunkowych oraz ich wpływ na procedurę uchwalania wieloletniej prognozy finansowej jednostek samorządu terytorialnego.

Słowa kluczowe: wieloletnia prognoza finansowa, zadłużenie jednostek samorządu terytorialnego, regionalne izby obrachunkowe
\end{abstract}


Marika Musmanow - Charakter prawny i rola wieloletniej prognozy...

\begin{abstract}
:
Long-term projection was to be a modern instrument in management of local government finances, be a document and a legal act at the same time, that allows a financial stability in local authorites. The purpose of this article is to indicate what is the role of long-term financial projection in the context of growing liability of local government units. As advantages of long-term planing the following are listed: more reasonable management of public resources, improving the reliability, clarity and predictability of the fiscal policy or matching it with the one at the EU level. Liability in local government is an especially important problem, because for many years a debt ratio in local government remained at very high level. Apart from indicating the role of long-term projection, the article also discusses the issue of adopting a financial forecast, at the same time, underlining the role of regional chambers of audit and their influence on the long-term projection of local government decision-making process.
\end{abstract}

Keywords: long-term projection, liability of local government units, regional chambers of audit

\title{
Wprowadzenie
}

Podstawowym aktem związanym z gospodarką finansową jednostki samorządu terytorialnego (dalej JST) jest, stosownie do art. 211 ustawy z dnia 27 sierpnia 2009 r. o finansach publicznych (dalej UFP) ${ }^{1}$, uchwała budżetowa. Obok uchwały budżetowej w samorządach mamy również do czynienia z tworzeniem wieloletniej prognozy finansowej (dalej WPF). Taka prognoza powinna być przede wszystkim realistyczna oraz ma umożliwiać sprawne zarządzanie finansami samorządowymi. Każda JST, wykonując określone zadania, musi dysponować niezbędnymi zasobami finansowymi, które umożliwią ich realizację. Dlatego zarówno uchwała budżetowa, jak i właśnie WPF mają pomóc danej JST tak dopasować określone wielkości, żeby były one adekwatne do osiąganych dochodów samorządu terytorialnego, aby w konsekwencji móc je przeznaczyć na planowane wydatki.

Wieloletnia prognoza finansowa miała m.in. pomóc JST uchronić się przed rosnącym zadłużeniem. Jak wskazywano w uzasadnieniu do

\footnotetext{
1 Ustawa z dnia 27 sierpnia 2009 r. o finansach publicznych (t.j. Dz.U. z 2019 r., poz. 869).
} 
rządowego projektu UFP z dnia 20 października 2008 r. (dalej uzasadnienie do projektu UFP z 2008 r.) $)^{2}$, planowanie wieloletnie uznawane jest przez współczesną naukę za niezbędny instrument nowoczesnego zarządzania finansami publicznymi. Występuje ono także w gospodarce finansowej Unii Europejskiej, stąd też zasadne jest przyjęcie podobnego systemu w Polsce. W samorządach mamy do czynienia $\mathrm{z}$ decentralizacją władzy publicznej. Uczestnicząc w sprawowaniu władzy publicznej, JST wykonują określone zadania we własnym imieniu oraz na własną odpowiedzialność, co oznacza, że wykonują je w oparciu o własne środki. Samorząd terytorialny musi tak zaplanować zarówno dochody jak i wydatki publiczne, aby wystarczyły one na zaspokajanie potrzeb mieszkańców wspólnoty bez konieczności zadłużania się, w tym zaciągania pożyczek czy kredytów. W sytuacji natomiast konieczności posiłkowania się przychodami zwrotnymi zaplanować dług oraz koszty obsługi zadłużenia wieloletniego z uwzględnieniem możliwości finansowych JST.

Celem niniejszego artykułu jest przede wszystkim próba odpowiedzi na pytanie, jaką rolę spełnia WPF w kontekście rosnącego zadłużenia JST i czy faktycznie jest to dokument finansowy, który pozwala uchronić się przed nadmiernym zadłużaniem. Wieloletnia prognoza finansowa jest dokumentem strategicznym, w którym rzetelne sformułowanie danych ma na celu przede wszystkim tak dopasować określone wartości przyjęte zarówno w WPF, jak i w budżecie JST, żeby były one zgodne w zakresie wyniku budżetu, a także długu JST (art. 229 UFP).

Zadłużenie w samorządzie stanowi bardzo ważny problem, ponieważ przez wiele lat wskaźnik zadłużenia utrzymywał się na bardzo wysokim poziomie w wielu JST. Od $2014 \mathrm{r}$. funkcjonuje w samorządzie terytorialnym indywidualny wskaźnik - determinujący w istocie możliwość zadłużania się JST. Decyduje on o kształtowaniu się relacji wiel-

\footnotetext{
2 Uzasadnienie do rządowego projektu ustawy o finansach publicznych, druk sejmowy nr 1181 z dnia 20 października 2008 r., http://orka.sejm.gov.pl/Druki6ka.nsf/ wgdruku/1181 [dostęp: 22-02-2019].
} 
Marika Musmanow - Charakter prawny i rola wieloletniej prognozy...

kości obsługi długu do środków, które można przeznaczyć na jego spłatę. Wprowadzenie regulacji związanych z art. 243 UFP w zarządzaniu długiem samorządowym pozwala dostosować limit długu do możliwości finansowych poszczególnych JST, a co najważniejsze, pozwala ograniczać zadłużenie w samorządzie. Dlatego też planowanie stanowi podstawową funkcję $\mathrm{w}$ procesie zarządzania $\mathrm{w}$ samorządzie terytorialnym, aby cele wyznaczone przez JST mogły być realizowane w sposób jak najbardziej efektywny przy wykorzystywaniu dostępnych środków finansowych.

Obok wskazania na rolę WPF $\mathrm{w}$ artykule przedstawiono również charakter prawny WPF oraz kwestie związane z uchwalaniem prognozy finansowej, jednocześnie podkreślając rolę regionalnych izb obrachunkowych (dalej RIO) oraz ich wpływ na procedurę uchwalania WPF jednostek samorządu terytorialnego. W artykule również omówiono zmiany w zakresie WPF oraz kwestii zadłużania JST, które nastąpiły w związku z nowelizacją UFP z 2018 r. Ponadto wskazano na nowy rodzaj opinii, jaką wydaje RIO zgodnie z nowelizacją UFP z 2018 r.

\section{Pojęcie oraz zakres wieloletniej prognozy finansowej}

Należy zaznaczyć, że wprowadzenie WPF do systemu finansów publicznych było jednym z głównych założeń ustawy z dnia 27 sierpnia 2009 r. o finansach publicznych. Miała ona na celu stworzenie realnych podstaw do określenia kierunków polityki finansowej zarówno państwa, jak i JST w odpowiednio długim horyzoncie czasowym³ ${ }^{3}$.

$\mathrm{W}$ jednostkach samorządu terytorialnego na potrzeby zarządzania poszczególnymi obszarami ich funkcjonowania zarówno finansami, gospodarką komunalną, jak i majątkiem rzeczowym tworzonych jest wiele różnego rodzaju dokumentów oraz opracowań. Warto zwrócić uwagę, że część z nich ma charakter obligatoryjny, część charakter fakultatywny, jedne mają rangę uchwał, inne są raportami, sprawozdaniami

\footnotetext{
${ }^{3}$ K. Sawicka, Wieloletnia prognoza finansowa, [w:] M. Miemiec, W. Miemiec, K. Sawicka, Prawo finansów publicznych sektora samorzadowego, Warszawa 2013, s. 62.
} 
czy też informacjami. Przepisy o WPF jednostek samorządu terytorialnego są konsekwencją obowiązku tworzenia właśnie od 2011 r. wieloletniego planu finansowego państwa, jak również są rozwinięciem regulacji dotyczących sporządzanych do tej pory w JST wieloletnich planów inwestycyjnych ${ }^{4}$.

Warto zaznaczyć, że zanim została unormowana materia związana z WPF w ustawie o finansach publicznych, w piśmiennictwie zaczęto wskazywać na konieczność modyfikacji stanowiska dotyczącego stanowienia budżetu JST. Miała ona polegać na odejściu od procedury planistycznej opartej na roku budżetowym do układu wieloletniego kroczącego. Sprzyja to przede wszystkim zarówno większej racjonalizacji wydatków inwestycyjnych, jak i wydatków bieżących ${ }^{5}$. Właśnie od 1 stycznia 2010 roku WPF stanowi istotny instrument zarządzania finansami w poszczególnych JST, będąc jednocześnie dokumentem oraz aktem prawnym, który umożliwia wydłużenie okresu planowania, a przede wszystkim umożliwia zachowanie stabilizacji finansowej w samorządzie terytorialnym 6 .

Jeżeli chodzi o uregulowanie WPF w ustawie o finansach publicznych, to poświęcono jej dział V rozdziału II. Została ona uregulowana zaledwie w kilku artykułach, a mianowicie od art. 226 do art. 232 UFP. Wieloletnia prognoza finansowa wraz z budżetem stanowi zasadniczy dokument finansowy JST. Jednakże w UFP nie odnajdziemy legalnej definicji WPF.

Niemniej jednak na podstawie regulacji zawartych w art. 226-229 UFP można przyjąć, że wieloletnia prognoza finansowa jest wieloletnim planem finansowo-rzeczowym JST ustalanym w formie uchwały

${ }^{4}$ J. Kotlińska, Wieloletnia prognoza finansowa - jak rozumieć przepisy ustawowe, aby je prawidłowo stosować, „Finanse Komunalne” 2010, nr 10, s. 3-23.

${ }^{5} \mathrm{~K}$. Nizioł, Dług publiczny jednostek samorzqdu terytorialnego jako element ich wieloletniej prognozy finansowej - wybrane aspekty prawno-ekonomiczne, [w:] A. Drywa, J. Gliniecka, E. Juchniewicz, T. Sowiński (red.), Finansowanie jednostek samorzq̨du terytorialnego, Warszawa 2016, s. 82.

6 Z. Ofiarski, Istota zwiq̨zku uchwały w sprawie wieloletniej prognozy finansowej $z$ uchwała budżetowa jednostki samorządu terytorialnego - aspekty formalnoprawne i materialnoprawne, „Finanse, Rynki finansowe, Ubezpieczenia” 2016, nr 6, s. 40. 
Marika Musmanow - Charakter prawny i rola wieloletniej prognozy...

organu stanowiącego, która ma pełnić funkcję instrumentu strategicznego zarządzania finansami lokalnymi ${ }^{7}$. Warto $\mathrm{w}$ tym miejscu odnieść się do nowelizacji UFP i w tym zakresie wskazać na ustawę z dnia 14 grudnia 2018 r. o zmianie ustawy o finansach publicznych oraz niektórych innych ustaw (dalej nowelizacja UFP z 2018 r.) ${ }^{8}$, która dokonała znaczących zmian w zakresie m.in. WPF i kwestii dotyczących zadłużania JST. Jak wskazywano w uzasadnieniu do rządowego projektu ustawy o zmianie ustawy o finansach publicznych oraz niektórych innych ustaw z dnia 17 lipca 2018 r. (dalej uzasadnienie do projektu UFP z 2018 r.) ${ }^{9}$, znowelizowana ustawa zmierza przede wszystkim do zracjonalizowania możliwości zadłużania się samorządów, uelastycznienia ich gospodarki finansowej oraz wzmocnienia mechanizmów prawnych służących zwiększeniu bezpieczeństwa finansowego. Większość zaproponowanych zmian weszło w życie z dniem 1 stycznia $2019 \mathrm{r}$.

Wieloletnia prognoza finansowa wzorowana jest przede wszystkim na wprowadzonej przepisami UFP instytucji wieloletniego planu finansowego państwa, uregulowanej w art. 103-108 UFP. Wieloletnia prognoza finansowa obejmuje okres roku budżetowego oraz co najmniej trzech kolejnych lat budżetowych, przy czym część WPF stanowi prognoza kwoty długu sporządzana na okres, na który zaciągnięto oraz planuje się zaciągnąć zobowiązania ${ }^{10}$. Przy czym należy zaznaczyć, że WPF nie ma charakteru bezwzględnie obowiązującego, ponieważ

7 E. Czołpińska, J. M. Salachna, Wieloletnia prognoza finansowa j.s.t., [w:] C. Kosikowski, J. M. Salachna (red.), Finanse samorzqdowe. 580 pytań i odpowiedzi, Warszawa 2012, s. 429.

8 Ustawa z dnia 14 grudnia 2018 r. o zmianie ustawy o finansach publicznych oraz niektórych innych ustaw (Dz.U. z 2018 r., poz. 2500).

9 Uzasadnienie do rządowego projektu ustawy o zmianie ustawy o finansach publicznych oraz niektórych innych ustaw, druk sejmowy nr 2787 z dnia 17 lipca 2018 r. http://www.sejm.gov.pl/Sejm8.nsf/druk.xsp?nr=2787 [dostęp: 25-02-2019].

10 G. Czarnocki, K. Stelmaszczyk, Kształtowanie się prawnych instrumentów zaciągania przez gminę zobowiązań wykraczających poza ramy roku budżetowego na przestrzeni dotychczasowej działalności regionalnych izb obrachunkowych, [w:] P. R. Krawczyk, M. Stec (red.), Samorząd - Finanse - Nadzór i kontrola. XX-lecie Regionalnych Izb Obrachunkowych, Lex/el. 2013. 
możliwe są zmiany prognozy, o ile ich zakres i sposób dokonania są zgodne z regułami zawartymi w UFP. Zmian może dokonywać zarząd JST, z wyłączeniem zmian w wydatkach na realizację przedsięwzięć wieloletnich, które mogą być dokonywane wyłącznie w oparciu o uchwałę organu stanowiącego tej jednostki. Wieloletnia prognoza finansowa ma charakter „kroczący”, na co wskazuje art. 231 UFP, co oznacza, że co roku wydłuża się jej zakres czasowy ${ }^{11}$.

Jeżeli chodzi o dokonywanie zmian w WPF, to należy tutaj odnieść się do zmodyfikowanego art. 232 UFP dokonanego nowelizacją UFP z 2018 r. Przepis ten umożliwia organowi wykonawczemu JST dokonywanie zmian w budżecie i WPF jednostki w związku z realizacją projektów finansowanych z udziałem środków europejskich. W art. 232 UFP wprowadzono możliwość upoważnienia zarządu przez organ stanowiący JST do zmian limitów zobowiązań i wydatków na realizację przedsięwzięcia finansowanego z udziałem środków europejskich albo środków, o których mowa w art. 5 ust. 1 pkt 3 UFP, w związku ze zmianami w realizacji tego przedsięwzięcia, o ile zmiany te nie pogorszą wyniku budżetu dla każdego roku objętego prognozą. Przepis art. 232 UFP stanowi ustawowe upoważnienie dla zarządu JST do dokonywania zmian w WPF, jak również stanowi podstawę prawną do zmiany w treści WPF w związku ze zmianą uchwały budżetowej. Jednakże należy pamiętać, że kompetencje zarządu JST, które wynikają $\mathrm{z}$ art. 232 UFP, są ograniczone do zmian mających zapewnić zgodność WPF z uchwałą budżetową $\mathrm{w}$ danym roku budżetowym ${ }^{12}$.

Wieloletnia prognoza finansowa jako instrument zarządzania finansami wymaga przede wszystkim m.in. odniesienia się do przyszłości z zachowaniem jednocześnie spójności oraz ciągłości, jeśli chodzi o teraźniejszość; przewidywania, szacowania, uwzględnienia ryzyka oraz prawdopodobieństwa jego wystąpienia w celu oszacowania kształto-

${ }^{11}$ M. Bitner, E. Kornberger-Sokołowska, Prawo finansów samorzq̨dowych, Warszawa 2018, s. 50.

12 P. Lenio, Art. 232, [w:] Z. Ofiarski (red.), Ustawa o finansach publicznych. Komentarz, Lex/el. 2019. 
Marika Musmanow - Charakter prawny i rola wieloletniej prognozy...

wania się przyszłych zdarzeń, mających wpływ na finanse JST. Planowanie wymaga również woli działania, czyli realności jego wykorzystania pod kątem osiągania zakładanych celów związanych z gospodarowaniem finansami, opracowania celów i mierników ich osiągnięcia, dokonywania wyborów, co oznacza, że planując, wybieramy określoną alternatywę dotyczącą przyszłych zjawisk oraz działań ${ }^{13}$.

Zakres WPF został wskazany w art. 226 UFP. Zgodnie z tym WPF powinna być realistyczna oraz powinna określać dla każdego roku objętego prognozą co najmniej: dochody bieżące oraz wydatki bieżące budżetu jednostki samorządu terytorialnego, w tym na obsługę długu, gwarancje i poręczenia; dochody majątkowe, w tym dochody ze sprzedaży majątku, oraz wydatki majątkowe budżetu jednostki samorządu terytorialnego; wynik budżetu jednostki samorządu terytorialnego; przeznaczenie nadwyżki albo sposób sfinansowania deficytu; przychody i rozchody budżetu jednostki samorządu terytorialnego z uwzględnieniem długu zaciągniętego oraz planowanego do zaciągnięcia; kwotę długu jednostki samorządu terytorialnego oraz sposób sfinansowania jego spłaty; kwoty wydatków bieżących i majątkowych wynikających z limitów wydatków na planowane i realizowane przedsięwzięcia.

Zakres danych WPF określonych w art. 226 UFP zmierza przede wszystkim do uczynienia dokumentu przejrzystego oraz zrozumiałego nie tylko dla służb finansowych JST czy też RIO, ale także dla szerszego kręgu osób zainteresowanych sytuacją finansową danej JST. Ponadto zaletami takiej konstrukcji danych WPF jest, po pierwsze, ujęcie w jednym dokumencie prognozy kwoty długu w sposób, umożliwiający RIO weryfikację prognozowanych danych w całym okresie, na który zaciągnięto i planuje się zaciągnąć dług oraz, po drugie, pokazanie w WPF wszystkich przepływów finansowych w sposób przyczynowo-skutkowy. Ma to ułatwić zainteresowanym osobom zrozumienie tego dokumentu. Wieloletnia prognoza finansowa powinna przyczynić się rów-

13 M. Dylewski, Problemy wykorzystania WPF $w$ zarzadzaniu finansami jednostki samorzadu terytorialnego, „Studia Ekonomiczne. Zeszyty Naukowe Uniwersytetu Ekonomicznego w Katowicach" 2016, nr 273, s. 50-51. 
nież do realizacji zasady jawności, a także do zasady przejrzystości finansów publicznych ${ }^{14}$. Zgodnie $\mathrm{z}$ art. 33 UFP gospodarka środkami publicznymi jest jawna. Zasada jawności powinna opierać się przede wszystkim na swobodnym dostępie każdego obywatela do informacji finansowych. Jest ona realizowana m.in. poprzez właśnie jawność debaty nad projektem uchwały w sprawie WPF. Natomiast zgodnie z zasadą przejrzystości dane ujęte w WPF powinny być bezwzględnie zrozumiałe dla każdego mieszkańca danej JST.

Ważnym elementem w WPF jest również wieloletnia prognoza długu. Pokazuje ona na przestrzeni kolejnych lat poziom zadłużenia z tytułu zaciągniętych kredytów i pożyczek, wyemitowanych obligacji komunalnych oraz przyjętych depozytów, wskaźnik i sposób spłaty długu w poszczególnych latach, jak również indywidualny dla danej JST limit obciążenia budżetu spłatą długu wraz z kosztami jego obsługi oraz spłatami udzielonych poręczeń i gwarancji. Czas, na jaki opracowywana jest taka prognoza długu, obejmuje okres, na który zaciągnięto oraz planuje się zaciągnąć określone zobowiązania ${ }^{15}$. Ponadto obok wieloletniej prognozy długu bardzo ważnym załącznikiem do uchwały w sprawie WPF jest wykaz przedsięwzięć planowanych do zrealizowania przez daną JST. Przez przedsięwzięcia należy rozumieć wszelkiego rodzaju programy, projekty lub zadania, umowy, których realizacja w roku budżetowym i latach następnych jest niezbędna do zapewnienia ciągłości działania danej jednostki i z których wynikające płatności wykraczają poza rok budżetowy, jak również gwarancje oraz poręczenia udzielane przez JST ${ }^{16}$. Należy tutaj też wskazać na art. 90 UFP dokonany nowelizacją UFP z 2018 r. Zgodnie z tym artykułem:

${ }^{14}$ S. Bogacki, A. Bulzak, Wieloletnie Prognozy Finansowe jako narzędzie rozwoju jednostki samorządu terytorialnego, „Zeszyty Naukowe WSEI Ekonomia” 2012, 5 (2), s. 58-59.

15 K. Sawicka, Wieloletnia prognoza finansowa..., op. cit., s. 64.

$16 \mathrm{~K}$. Owsiak, Wieloletnia prognoza finansowa jako instrument zarzadzania finansami jednostek samorzqdu terytorialnego, „Studia Ekonomiczne. Zeszyty Naukowe Uniwersytetu Ekonomicznego w Katowicach” 2014, nr 198, s. 169. 
Marika Musmanow - Charakter prawny i rola wieloletniej prognozy...

Na finansowanie wydatków na inwestycje i zakupy inwestycyjne, w tym ujęte w ramach przedsięwzięć, o których mowa w art. 226 ust. 3, jednostki samorządu terytorialnego mogą zaciągać pożyczki $\mathrm{w}$ państwowych funduszach celowych oraz w państwowych i samorządowych osobach prawnych zaliczanych do sektora finansów publicznych, o ile ustawa tworząca fundusz lub osobę prawną tak stanowi.

Kolejna kwestia to zgodność WPF z budżetem JST. Wykorzystanie WPF do skutecznego zarządzania finansami lokalnymi wymaga respektowania zasady uprzedniości oraz nadrzędności WPF. Dlatego też WPF powinna pełnić jako plan ogólny funkcje nadrzędne w stosunku do budżetu rocznego, natomiast ewentualne różnice pomiędzy budżetem, a obowiązującą prognozą powinny być uzależnione od uprzedniej zmiany WPF. Planowanie wieloletnie w samorządzie terytorialnym jedynie w ograniczonym zakresie zachowuje wpływ na kształtowanie budżetu danego roku, dotyczy to przede wszystkim limitów zobowiązań i kwot wydatków na przedsięwzięcia oraz kwoty długu, jego spłat wraz z kosztami obsługi i spłat udzielonych poręczeń i gwarancji w poszczególnych latach ${ }^{17}$.

Można stwierdzić, że WPF stanowi wytyczną działania dla władz publicznych: wprowadza ustalenia w zakresie ogólnych danych finansowych, jak również zakładanych kierunków kształtowania się sytuacji finansowej. Wieloletnia prognoza finansowa dotyczy publicznej gospodarki finansowej, w uporządkowany sposób ujmuje w liczby działalność finansową organów wykonawczych. Zawiera ona również wskazówki oraz wytyczne i jest poniekąd swego rodzaju przewodnikiem ${ }^{18}$.

\section{WPF jako instrument ograniczający poziom zadłużenia w JST}

W literaturze bardzo mocno podkreśla się rolę oraz znaczenie WPF. Należy zaznaczyć, że dobrze oszacowana oraz zaprojektowana prognoza finansowa może niewątpliwie przyczynić się do zniwelowania

\footnotetext{
17 K. Sawicka, Wieloletnia prognoza finansowa ..., op. cit., s. 68-69.

18 A. Borodo, Samorząd terytorialny. System prawnofinansowy, Warszawa 2012, s. 223.
} 
długu w JST, co oznacza, że zadłużenie w danym samorządzie będzie zdecydowanie mniejsze. Dlatego ważne jest, aby wszelkie dochody, wydatki czy też kwoty dotyczące długu zawarte w WPF skonstruować tak, żeby faktycznie odzwierciedlały stan finansowy JST i nie doprowadzały do jeszcze większego zadłużenia w samorządzie. Rola WPF w tym zakresie sprowadza się do ograniczenia zadłużenia w JST, jak również pozwala nadzorować poziom zadłużenia danego samorządu.

Niewątpliwie zarządzanie środkami publicznymi ma ułatwić ujęcie w jednym akcie podjętych przez organy gminy decyzji oraz ich konsekwencji - np. w odniesieniu do planowanych inwestycji bądź też zadłużenia JST - co spowoduje przede wszystkim wzrost odpowiedzialności za podejmowane decyzje nie tylko organu wykonawczego, ale również organu stanowiącego gminy ${ }^{19}$. Warto zwrócić uwagę, że w uzasadnieniu do projektu UFP z 2008 r. jako zalety planowania wieloletniego wymieniono, po pierwsze, bardziej racjonalne gospodarowanie środkami publicznymi, po drugie, zwiększenie wiarygodności, przejrzystości oraz przewidywalności polityki fiskalnej oraz, po trzecie, dopasowanie do planowania na szczeblu unijnym.

W piśmiennictwie akcentuje się rolę WPF, w wydłużeniu perspektywy planowania budżetowego $\mathrm{w}$ samorządzie terytorialnym w porównaniu do tradycyjnego, tj. jednorocznego okresu charakterystycznego dla uchwały budżetowej ${ }^{20}$. Niewątpliwie planowanie jako podstawowa funkcja procesu zarządzania stopniowo staje się jednym z podstawowych zakresów aktywności w procesie zarządzania w JST. Polega ona na projektowaniu pożądanego obrazu przyszłości oraz wskazania metod i dróg jego najefektywniejszego osiągnięcia. Ponadto WPF pozwala szacować przyszłe dochody i wydatki JST oraz poziomy nadwyż-

${ }^{19}$ G. Czarnocki, K. Stelmaszczyk, Kształtowanie się prawnych instrumentów zaciagania przez gminę zobowiq̨zań wykraczających poza ramy roku budżetowego na przestrzeni dotychczasowej działalności regionalnych izb obrachunkowych..., op. cit., Lex/el. 2013.

20 Z. Ofiarski, Wieloletnia Prognoza Finansowa $w$ orzecznictwie regionalnych izb obrachunkowych i sądów administracyjnych, [w:] M. Będzieszak, T. Lubińska, N. Marska-Dzioba (red.), Zarządzanie finansami publicznymi a efektywność, Warszawa 2015, s. 358. 
Marika Musmanow - Charakter prawny i rola wieloletniej prognozy...

ki bądź też deficytu, tj. czynników, które decydują o skali kredytowania i kosztach obsługi zobowiązań zaciągniętych oraz przewidzianych do zaciągnięcia ${ }^{21}$.

Wieloletnia prognoza finansowa ma również ułatwiać władzom samorządowym dokonywanie racjonalnego wyboru średnio- i długookresowych celów oraz finansowych i rzeczowych instrumentów ich osiągania. Ma ona także ułatwiać zachowanie płynności oraz wypłacalności JST, a przez to przyczyniać się do utrzymania na bezpiecznym poziomie łącznych rozmiarów państwowego długu publicznego. Ponadto ułatwia ona także współpracę JST z przedsiębiorcami, bankami lub organizacjami pozarządowymi ${ }^{22}$. Najważniejszym elementem planowania wieloletniego jest również zdolność do przygotowania możliwie najbardziej precyzyjnej prognozy dochodów oraz wydatków z uwzględnieniem wpływu różnych czynników na warunki prowadzenia gospodarki finansowej w kolejnych latach ${ }^{23}$.

Warto zauważyć, że WPF pełni także istotną rolę w wykrywaniu obszarów działania o niskiej efektywności. Można wówczas wskazać na pewne funkcje, takie jak: możliwość stosowania minimalizacji kosztów pozyskania długu oraz minimalizacji kosztów obsługi długu przy zapewnieniu płynności finansowej JST. WPF umożliwia także doprecyzowanie momentu zaciągania długu, generowanie prognoz ostrzegawczych, wyjaśnianie celowości przygotowania alternatywnych scenariuszy planu finansowego oraz przede wszystkim poprawę jakości oraz efektywności zarządzania. Szczególna rola WPF polega głównie na tym, że skupia ona w sobie wszystkie najważniejsze obszary działalności JST, umożliwia również samorządom racjonalne wykorzystanie zdobytych środków, zwiększa wiarygodność finansową

${ }^{21}$ M. Piszczek, Wieloletnie planowanie finansowe $w$ samorzqdzie, „Prace Naukowe Uniwersytetu Ekonomicznego we Wrocławiu” 2017, nr 485, s. 364-365.

22 A. Babczuk, E. Pudło, Wieloletnie prognozy finansowe jednostek samorzqdu terytorialnego $w$ ocenie regionalnych izb obrachunkowych, „Finanse Komunalne” 2011, nr 7-8, s. 76-84.

23 S. Bogacki, A. Bulzak, Wieloletnie Prognozy Finansowe jako narzędzie rozwoju jednostki samorzq̨du terytorialnego..., op. cit., s. 46. 
gminy i poprawia dostęp do zewnętrznych źródeł finansowania ${ }^{24}$. Trzeba tutaj przede wszystkim odnieść się do zmian, jakie zostały wprowadzone nowelizacją UFP z 2018 r. Jak wskazywano w uzasadnieniu do projektu UFP z 2018 r., jedna ze zmian odnosi się właśnie do zracjonalizowania możliwości zadłużania się samorządów. Dodany w art. 243 ust. 3b UFP umożliwia dokonanie restrukturyzacji oraz wcześniejszej spłaty długu JST, podczas gdy wcześniej możliwość restrukturyzacji zadłużenia zależała od nadwyżki w części bieżącej. Zmiana ta ma na celu umożliwić wcześniejszą spłatę zadłużenia w przypadku posiadania przez JST środków finansowych na ten cel oraz pozwala tym samym na zmniejszenie długu publicznego i kosztów jego obsługi.

Obok zalet możemy jednakże wskazać również na pewne wady WPF. Tymi wadami może być: wieloletni i kosztowny proces wprowadzania planowania wieloletniego, możliwość zmniejszenia elastyczności polityki fiskalnej czy wybór horyzontu planowania - krótki, czyli możliwość przenoszenia wydatków na następne lata czy długi, kiedy prognoza obarczona jest większym błędem. Jednakże w opinii projektodawcy korzyści wynikające z zalet WPF przeważają nad wadami, co tym samym przemawia za zastosowaniem tego typu instrumentów w polskim systemie finansów publicznych ${ }^{25}$. Jak podkreślano w uzasadnieniu do projektu UFP z 2008 r., biorąc pod uwagę analizę korzyści i kosztów, bilans i tak wydaje się dodatni, dlatego zaproponowano wprowadzenie instytucji WPF.

Jak już wcześniej wskazywano, główną rolą WPF jest ograniczenie zadłużenia JST. Obowiązkowe w Polsce od 2010 r. WPF jednostek samorządu terytorialnego zawierają m.in. projekcje zadłużenia jednostki oraz wskazanie zdolności do wypełniania przez nią w przyszłości

${ }^{24}$ K. S. Cichocki, Wieloletnie planowanie $w$ zarzq̨dzaniu finansami jednostek samorzq̨du terytorialnego, [w:] J. Gutenbaum (red.), Zarządzanie finansami i długiem samorzq̨du terytorialnego perspektywie wieloletniej, Warszawa 2013, s. 34-36.

25 M. Tyniewicki, Wieloletnia prognoza finansowa jako podstawa gospodarki finansowej jednostki samorządu terytorialnego, [w:] P. Borszowski, J. M. Salachna, K. Stelmaszczyk (red.), Prawo i Administracja dla Regionu. Zagadnienia prawnofinansowe, Wałbrzych 2016, s. 24. 
Marika Musmanow - Charakter prawny i rola wieloletniej prognozy...

prawnych limitów długu, dlatego też plany są doskonałym źródłem danych do przeprowadzenia badania, w jaki sposób samorządy projektują swoje zadłużenie, $w$ tym jakie jest obciążenie jednostek długiem oraz jego obsługą, jak również w jakim stopniu limity zadłużenia, które mają od $2014 \mathrm{r}$. indywidualny charakter, będą ograniczać potencjał zadłużeniowy samorządów ${ }^{26}$. Jest to bardzo ważna rola WPF, ponieważ wskaźnik zadłużenia sektora samorządowego od blisko 15 lat utrzymuje się na bardzo wysokim poziomie. Kryzys w sposób szczególny przede wszystkim dotyka gminę, która ze względu na podstawowy oraz pierwotny szczebel podziału administracyjnego kraju realizuje największy szereg ustawowo nałożonych zadań. Dlatego też w ograniczaniu zadłużenia JST ogromnego znaczenia nabierają obecnie dwa instrumenty, a mianowicie funkcjonująca od 2011 r. WPF oraz działający w praktyce od $2014 \mathrm{r}$. indywidualny wskaźnik zadłużenia JST27. Ustawa z dnia 14 grudnia 2018 r. o zmianie ustawy o finansach publicznych oraz niektórych innych ustaw znowelizowała art. 243 ust. 1 UFP, gdzie wyeliminowano dochody ze sprzedaży majątku przy wyliczaniu indywidualnego wskaźnika zadłużenia. W uzasadnieniu do projektu UFP z 2018 r. zaproponowano doprecyzowanie limitu spłaty zobowiązań poprzez wyeliminowanie sprzedaży majątku jako elementu poprawiającego doraźnie sytuację JST i zachęcającego do pozbywania się majątku samorządowego tylko w celu poprawy wskaźnika.

Zarządzanie długiem polega głównie na badaniu oraz optymalizacji działań, które zmierzają do planowanego zaciągania i spłaty zobowiązań zgodnie z potrzebami oraz możliwościami finansowymi jednostki z uwzględnieniem sytuacji na rynkach finansowych. Kluczowy jest przede wszystkim odpowiedni wybór formy oraz źródeł pozyskiwania danych funduszy. Podejmując decyzję dotyczącą rodzaju długu, jak

${ }^{26}$ M. Wiśniewski, Dług samorządowy i jego limity w świetle wieloletnich prognoz finansowych jednostek samorzadu terytorialnego w Polsce, „Finanse Komunalne” 2014, nr 4, s. 20-29.

27 M. Jędrzejczyk, Rola wieloletniej prognozy finansowej jako narzędzia ograniczajqcego deficyt i dług publiczny gminy, „Nierówności społeczne a Wzrost Gospodarczy” 2014, nr 40, s. 98-99. 
również konstrukcji zobowiązania, należy kierować się przede wszystkim kwestią kosztów jego obsługi. Dlatego też, konieczne jest bieżące monitorowanie obsługi wcześniej zaciągniętych zobowiązań, a co za tym idzie wykorzystywanie $\mathrm{w}$ procesie zarządzania długiem WPF. Plany te, determinowane sformułowaną przez jednostkę strategią rozwoju, odgrywają istotną rolę w procesie określania zdolności jednostki do finansowania zadań bieżących, stąd też jednym z najważniejszych celów planowania finansowego jest właśnie zarządzanie długiem ${ }^{28}$. W wyniku nowelizacji UFP z 2018 r. art. 243 UFP zmierza do objęcia limitem spłaty zobowiązań JST, oprócz kredytów oraz pożyczek, wszystkich zobowiązań, które wywołują skutki ekonomiczne podobne do umowy pożyczki bądź kredytu. Zmiana ta ma przede wszystkim zapewnić RIO możliwość skutecznego wypełnienia funkcji nadzorczych i kontrolnych.

Prognoza kwoty długu oraz spłat zobowiązań obrazuje potencjał finansowy JST $w$ latach objętych prognozą z uwzględnieniem długu zarówno już posiadanego (zaciągniętego) przez JST, jak i planowanego do zaciągnięcia. $\mathrm{Z}$ całą pewnością na prognozę kwoty długu powinny się składać parametry niezbędne do oceny zachowania ustawowych wskaźników długu, jak i spłat dla poszczególnych lat ${ }^{29}$. Proces ten wymaga również od JST poprawy zarządzania gotówką, przewidzenia luk w jej przepływie oraz wiąże się z maksymalizowaniem przychodów z odsetek od kapitału. Wieloletnia prognoza finansowa, której częścią integralną jest prognoza długu i jego spłaty, jest obok budżetu najważniejszym dokumentem planowania finansowego. Prognoza długu należy do tych elementów WPF, które dają wyobrażenie o jakości wieloletniego planowania finansowego $w$ jednostce samorządowej oraz powinna obejmować wszystkie formy długu. Dlatego też w ramach pro-

${ }^{28}$ M. Wiśniewski, Planowanie finansowe $w$ zarządzaniu długiem samorzq̨dowym analiza dynamiczna na przykładzie województw samorządowych, „Kwartalnik Kolegium Ekonomiczno-Społecznego. Studia i Prace. Szkoła Główna Handlowa" 2016, nr 2, s. 106.

${ }^{29}$ E. Czołpińska, J. M. Salachna, Wieloletnia prognoza finansowa j.s.t..., op. cit., s. $440-441$. 
Marika Musmanow - Charakter prawny i rola wieloletniej prognozy...

wadzonej polityki zadłużenia jednym z najważniejszych zadań jest wyznaczenie optymalnego poziomu zadłużenia w sposób jak najbardziej odpowiedzialny oraz rzetelny ${ }^{30}$.

Określenie wskaźnika zdolności spłaty długu przez JST wymaga uwzględnienia w prognozie kwoty długu podstawowych parametrów budżetowych, takich jak prognozowane dochody, w tym dochody bieżące i dochody ze sprzedaży majątku, wydatki, w tym wydatki bieżące, wynik budżetu, jak również przychody oraz rozchody. Wielkości wskazanych parametrów budżetowych są konieczne do oceny prognozy długu określonych w art. 242 i 243 UFP reguł fiskalnych, co stanowi jedną z zasadniczych funkcji prognozy31. Niewątpliwie wydłużenie okresu prognozy w przypadku długu JST należy ocenić pozytywnie, ponieważ pozwala na wyodrębnienie spośród innych danych ujętych w WPF tak ważnej kwestii dla finansów samorządowych, jaką jest okres spłaty przez JST zobowiązań, które tworzą dług tej jednostki² ${ }^{32}$

\section{Procedura uchwalania oraz nadzór nad WPF sprawowany przez RIO}

Ważną kwestią jest również nadzór oraz kontrola nad uchwalaniem WPF. Główna rola w tym zakresie spoczywa na RIO, ponieważ zgodnie $\mathrm{z}$ art. 171 Konstytucji RP33 są one organami nadzoru nad samorządem terytorialnym w zakresie spraw finansowych. W tym celu RIO wydaje opinię oraz sprawdza, czy dana WPF została podjęta zgodnie z prawem i czy nie narusza odnośnych przepisów prawnych. W myśl art. 11 ust. 1 ustawy z dnia 7 października 1992 r. o regionalnych izbach obrachun-

30 M. Piszczek, Wieloletnie planowanie finansowe..., op. cit., s. 368.

${ }^{31}$ K. Sawicka, Wieloletnia prognoza finansowa..., op. cit., s. 64.

32 K. Nizioł, Dług publiczny jednostek samorzqdu terytorialnego jako element ich wieloletniej prognozy finansowej - wybrane aspekty prawno-ekonomiczne ..., op. cit., s. 86.

33 Konstytucja Rzeczypospolitej Polskiej z dnia 2 kwietnia 1997 r. (t.j. Dz.U. z 2009, nr 114, poz. 946). 
kowych (dalej ustawa o RIO) ${ }^{34}$ w zakresie działalności nadzorczej właściwość rzeczowa RIO obejmuje uchwały i zarządzenia podejmowane przez organy jednostek samorządu terytorialnego w sprawach m.in. właśnie wieloletniej prognozy finansowej i jej zmian.

Procedura sporządzania projektu i uchwalania prognozy jest podobna do procedury przygotowania projektu i uchwalania budżetu JST. Niemniej jednak WPF jest sporządzana i uchwalana niezależnie od uchwały budżetowej. Zgodnie $\mathrm{z}$ wytycznymi ministerstw finansów WPF powinno sporządzać się według następujących etapów: zebranie wiedzy o faktach, zebranie danych historycznych niezbędnych do prognozowania dochodów i wydatków, opracowanie prognozy dochodów, zebranie wiedzy o zamierzeniach i ryzykach, opracowanie wstępnej wersji WPF, a także analiza możliwości finansowych związanych z realizacją konkretnych przedsięwzięćc 35 .

Zgodnie z art. 230 UFP inicjatywa w sprawie sporządzenia projektu uchwały w sprawie wieloletniej prognozy finansowej i jej zmiany należy wyłącznie do zarządu jednostki samorządu terytorialnego. Następnie projekt uchwały w sprawie wieloletniej prognozy finansowej lub jej zmiany zarząd jednostki samorządu terytorialnego przedstawia wraz z projektem uchwały budżetowej po pierwsze regionalnej izbie obrachunkowej - celem zaopiniowania oraz po drugie organowi stanowiącemu jednostki samorządu terytorialnego. Uchwałę w sprawie WPF organ stanowiący podejmuje nie późnej niż uchwałę budżetową, czyli w terminie przed rozpoczęciem roku budżetowego, a w szczególnie uzasadnionych przypadkach nie później niż do 31 stycznia roku budżetowego.

Regionalna izba obrachunkowa, wykonując określone zadania nadzorcze oraz kontrolne nad uchwalaniem WPF, realizuje je w formie opinii, która jest wydawana na podstawie art. 230 ust. 3 UFP oraz art. 13

34 Ustawa z dnia 7 października 1992 r. o Regionalnych Izbach Rachunkowych (t.j. Dz.U. z 2018 r., poz. 2500).

$35 \mathrm{~K}$. Owsiak, Wieloletnia prognoza finansowa jako instrument zarządzania finansami jednostek samorządu terytorialnego..., op. cit., s. 168-169. 
Marika Musmanow - Charakter prawny i rola wieloletniej prognozy...

pkt 12 i art. 19 ust. 2 ustawy o RIO. W tym miejscu należy wskazać na nowy rodzaj opinii, jaką wydaje RIO w związku z nowelizacją art. 91 ust. 2 UFP. Zgodnie z art. 230 ust. 3 UFP opinię do projektu uchwały w sprawie wieloletniej prognozy finansowej lub jej zmiany, przedstawionego wraz z projektem uchwały budżetowej, regionalna izba obrachunkowa wydaje ze szczególnym uwzględnieniem zapewnienia przestrzegania przepisów ustawy dotyczących uchwalania i wykonywania budżetów w następnych latach, na które zaciągnięto i planuje się zaciągnąć zobowiązania. Następnie RIO na podstawie przyjętej przez JST wieloletniej prognozy finansowej przedstawia opinię $\mathrm{w}$ sprawie prawidłowości planowanej kwoty długu JST wynikającej z planowanych i zaciągniętych zobowiązań, o której mowa w art. 226 ust. 1 pkt 6. UFP. Warto również zauważyć, że jeżeli RIO wyda negatywną opinię co do prawidłowości planowanej kwoty długu JST, to wówczas JST zostanie zobligowana do dokonania takich zmian uchwał zarówno budżetowej, jak i WPF, które doprowadzą do zgodności relacji, o której mowa w art. 243 UFP. Rola RIO sprowadza się w tym zakresie do wydania dwóch opinii, w których dokonuje ona oceny treści najpierw z projektem, a dopiero później z przyjętą uchwałą budżetową.

Głównym celem tej kontroli jest przede wszystkim zapobieżenie działaniom w postaci podjęcia uchwały w sprawie WPF i jej zmiany sprzecznej z obowiązującymi w tym zakresie przepisami. Należy zaznaczyć, że w ustawie o RIO nie sformułowano kryterium stosowanego przy opiniowaniu przez składy orzekające danych aktów lub zamierzeń JST, jednak z pewnością można stwierdzić, że przy kontroli projektów WPF bądź też ich zmian takim kryterium jest legalność. Podstawowym argumentem, który przemawia za tym stwierdzeniem, jest art. 171 ust. 2 Konstytucji RP, który mówi, że właśnie RIO nadzorują działalność JST z punktu widzenia legalności ${ }^{36}$. Natomiast zgodnie ze zmodyfikowanym art. 91 ust. 2 UFP w związku z nowelizacją UFP z 2018 r. zarząd JST ma obowiązek pozyskania opinii RIO o możliwości

${ }^{36}$ E. Czołpińska, J. M. Salachna, Wieloletnia prognoza finansowa j.s.t..., op. cit., s. $450-451$. 
spłaty zadłużenia JST. Jak podkreślano $\mathrm{w}$ uzasadnieniu do projektu UFP z 2018 r., ma to na celu wzmocnienie mechanizmów, które pozwolą na bieżące monitorowanie przez organ nadzoru zobowiązań dłużnych JST. Zmiana ta ma przede wszystkim przyczynić się do zwiększenia bezpieczeństwa finansowego samorządu terytorialnego. Celem takiej opinii jest uwiarygodnienie JST jako potencjalnego kredytobiorcy, pożyczkobiorcy czy też emitenta papierów wartościowych. Jednakże opinia RIO nie ma charakteru wiążącego dla JST oraz dla podmiotów, które będą udzielały kredytu lub pożyczki bądź też nabywców obligacji. Oznacza to, że jeśli JST otrzyma opinię negatywną, to w żaden sposób nie wpłynie to na możliwości zaciągania zobowiązań, a jedynie może takie działanie utrudnić. Opinia RIO jest wymagana dla wszystkich zaciąganych przez JST kredytów, pożyczek, jak również emisji papierów wartościowych, bez względu na termin spłaty lub termin emisji37.

Następnie zgodnie z §5 pkt 1 rozporządzenia Ministra Finansów z 10 stycznia 2013 r. w sprawie wieloletniej prognozy finansowej jednostki samorządu terytorialnego ${ }^{38}$ RIO przekazują Ministrowi Finansów za pomocą aplikacji, o której mowa w §4 ust. 1, projekty wieloletnich prognoz finansowych jednostek samorządu terytorialnego wraz z wynikami opinii $\mathrm{w}$ terminie do dnia 31 grudnia roku poprzedzającego rok budżetowy. Przekazanie WPF Ministrowi Finansów należy do obowiązków RIO i ma zapewnić Ministrowi Finansów regularny dostęp do informacji finansowej o aktualnej prognozowanej sytuacji finansowej JST. Ma to istotne znaczenie zwłaszcza dla zarządzania długiem publicznym przez Ministra Finansów ${ }^{39}$. Zaopiniowaniu podlegają wyłącznie projekty przedstawiane corocznie wraz z projektem uchwały budżetowej. Następnie opinia składu orzekającego RIO

37 E. Kowalewska, Art. 91, [w:] Z. Ofiarski (red.), Ustawa o finansach publicznych. Komentarz, Lex/el. 2019.

38 Rozporządzenie Ministra Finansów z dnia 10 stycznia 2013 r. w sprawie wieloletniej prognozy finansowej jednostki samorządu terytorialnego (Dz.U. z 2013 r., poz. 86). s. 51.

${ }^{39}$ M. Bitner, E. Kornberger-Sokołowska, Prawo finansów samorzq̨dowych..., op. cit., 
Marika Musmanow - Charakter prawny i rola wieloletniej prognozy...

podlega opublikowaniu przez JST w terminie 7 dni od dnia jej otrzymania od RIO w Biuletynie Informacji Publicznej ${ }^{40}$.

Można stwierdzić, że nadzór nad uchwalaniem WPF jest bardzo ważny, ponieważ RIO jako organ nadzorczy gospodarki finansowej JST bada, czy dana WPF nie zawiera przepisów sprzecznych z prawem oraz czy nie została uchwalona $\mathrm{z}$ naruszeniem określonych przepisów prawnych. Jeżeli natomiast RIO wyda negatywną opinię dotyczącą WPF co do planowanej kwoty długu JST, ta ma obowiązek usunąć określone nieprawidłowości w odpowiednim terminie.

\section{Podsumowanie}

Odpowiadając na wyżej postawione pytanie, można zdecydowanie stwierdzić, że WPF odgrywa istotną rolę w zakresie zadłużenia JST, a zarazem stanowi bardzo ważny instrument w zarządzaniu finansami samorządowymi. Wieloletnia prognoza finansowa pozwala na minimalizowanie określonego zadłużenia danej JST, chociaż należy przy tym podkreślić, że aby tak się stało, taka prognoza musi być zdecydowanie realistyczna, a co więcej, powinna zawierać możliwie najdokładniej doprecyzowane dochody oraz wydatki, z uwzględnieniem różnych czynników wpływających na sytuację finansową samorządu terytorialnego. Wskazuje się również na szereg zalet oraz funkcji, jakie pełni WPF. Ma ona sprzyjać przede wszystkim bardziej racjonalnemu gospodarowaniu środkami publicznymi, jak również umożliwia wydłużenie okresu planowania, przez co pozwala na zachowanie stabilności finansowej w danej JST. Wieloletnia prognoza finansowa wymaga również odniesienia się do przyszłości, ponieważ pozwala ona szacować oraz przewidywać przyszłe zdarzenia, które mogą mieć wpływ na finanse samorządu terytorialnego. Co ważne, dobrze opracowana prognoza umożliwia również zachowanie płynności oraz wypłacalności danej JST, poprawia również efektywność w zarządzaniu finansami samorządowymi, dzięki czemu JST nie popadają w większe długi.

${ }^{40}$ A. Babczuk, E. Pudło, Wieloletnie prognozy finansowe..., op. cit., s. 76-84. 
Ważnym elementem, jaki zawiera w sobie WPF, jest prognoza kwoty długu, ponieważ pokazuje na przestrzeni kolejnych lat poziom zadłużenia danej JST w wyniku zaciągniętych kredytów, pożyczek, jak również wyemitowanych papierów wartościowych. Umożliwia także stosowanie minimalizacji kosztów pozyskania długu lub minimalizacji kosztów obsługi długu przy jednoczesnym zachowaniu płynności finansowej w samorządzie. Od 2014 r. ważną rolę odgrywa również indywidualny wskaźnik zadłużenia JST. Ma on wpływ na zadłużenie danej jednostki, ponieważ pozwala na dostosowanie poziomu spłat zobowiązań do możliwości finansowych danej JST, a co więcej chroni przed nadmiernym zadłużaniem się. Należy również wskazać, że znowelizowana UFP z 2018 r. ma istotne znaczenie zarówno dla budżetu jednostki samorządu terytorialnego, jak i dla wieloletniej prognozy finansowej, ponieważ wprowadzone zmiany mają na celu przede wszystkim zracjonalizowanie zadłużania się samorządów.

Dlatego można zdecydowanie stwierdzić, że WPF odgrywa bardzo ważną rolę w zakresie zadłużenia danej jednostki, pozwala szacować przyszłe dochody oraz wydatki i co najważniejsze, pozwala uchronić daną jednostkę przed narastającym zadłużeniem. Niewątpliwie dług samorządowy dzisiaj stanowi bardzo ważny problem dla każdej JST, a wprowadzona ustawą o finansach publicznych z 2009 r. WPF ma za zadanie właśnie temu zapobiegać. Z pewnością skala zadłużenia w samorządzie dzięki temu dokumentowi zdecydowanie spadła.

\section{Bibliografia:}

Babczuk A., Pudło E., Wieloletnie prognozy finansowe jednostek samorzqdu terytorialnego w ocenie regionalnych izb obrachunkowych, „Finanse Komunalne" 2011, nr 7-8.

Bitner M., Kornberger-Sokołowska E., Prawo finansów samorzq̨dowych, Wolters Kluwer, Warszawa 2018.

Bogacki S., Bulzak A., Wieloletnie Prognozy Finansowe jako narzędzie rozwoju jednostki samorzq̨du terytorialnego, „Zeszyty Naukowe WSEI Ekonomia”, $5(2 / 2012)$. 
Marika Musmanow - Charakter prawny i rola wieloletniej prognozy...

Borodo A., Samorzad terytorialny. System prawnofinansowy, Wyd. LexisNexis, Warszawa 2012.

Cichocki K. S., Wieloletnie planowanie $w$ zarządzaniu finansami jednostek samorzadu terytorialnego, [w:] J. Gutenbaum (red.), Zarządzanie finansami i długiem samorzqdu terytorialnego w perspektywie wieloletniej, Wyd. iBS PAN, Warszawa 2013.

Czarnocki G., Stelmaszczyk K., Kształtowanie się prawnych instrumentów zaciągania przez gminę zobowiq̨zań wykraczających poza ramy roku budżetowego na przestrzeni dotychczasowej działalności regionalnych izb obrachunkowych, [w:] P. R. Krawczyk, M. Stec (red.), Samorzqd - Finanse - Nadzór i kontrola. XX-lecie Regionalnych Izb Obrachunkowych, Lex/el. 2013.

Czołpińska E., Salachna J. M., Wieloletnia prognoza finansowa j.s.t., [w:] C. Kosikowski, J. M. Salachna (red.), Finanse samorzq̨dowe. 580 pytań i odpowiedzi, Wyd. Wolters Kluwer, Warszawa 2012.

Dylewski M., Problemy wykorzystania WPF $w$ zarzq̨dzaniu finansami jednostki samorzqdu terytorialnego, „Studia Ekonomiczne. Zeszyty Naukowe Uniwersytetu Ekonomicznego w Katowicach" 2016, nr 273.

Jędrzejczyk M., Rola wieloletniej prognozy finansowej jako narzędzia ograniczającego deficyt i dług publiczny gminy, „Nierówności Społeczne a Wzrost Gospodarczy" 2014, nr 40.

Konstytucja Rzeczypospolitej Polskiej z dnia 2 kwietnia 1997 r. (t.j. Dz.U. z 2009 r., nr 114, poz. 946).

Kotlińska J., Wieloletnia prognoza finansowa - jak rozumieć przepisy ustawowe, aby je prawidłowo stosować, „Finanse Komunalne” 2010, nr 10.

Nizioł K., Dług publiczny jednostek samorzqdu terytorialnego jako element ich wieloletniej prognozy finansowej - wybrane aspekty prawno-ekonomiczne, [w:] A. Drywa, J. Gliniecka, E. Juchniewicz, T. Sowiński (red.), Finansowanie jednostek samorządu terytorialnego, Wyd. CeDeWu, Warszawa 2016.

Ofiarski Z., Istota zwiqzzu uchwały w sprawie wieloletniej prognozy finansowej z uchwała budżetowq jednostki samorzqdu terytorialnego - aspekty formalnoprawne i materialnoprawne, „Finanse, Rynki finansowe, Ubezpieczenia” 2016, nr 6.

Ofiarski Z., (red.), Ustawa o finansach publicznych. Komentarz, Lex/el. 2019.

Ofiarski Z., Wieloletnia Prognoza Finansowa w orzecznictwie regionalnych izb obrachunkowych i sq̨dów administracyjnych, [w:] M. Będzieszak, T. Lubińska, N. Marska-Dzioba (red.), Zarzq̨dzanie finansami publicznymi a efektywność, Wyd. Difin, Warszawa 2015. 
Owsiak K., Wieloletnia prognoza finansowa jako instrument zarzq̨dzania finansami jednostek samorzadu terytorialnego, „Studia Ekonomiczne. Zeszyty Naukowe Uniwersytetu Ekonomicznego w Katowicach” 2014, nr 198.

Piszczek M., Wieloletnie planowanie finansowe w samorządzie, „Prace naukowe Uniwersytetu Ekonomicznego we Wrocławiu” 2017, nr 485.

Sawicka K., Wieloletnia prognoza finansowa, [w:] M. Miemiec, W. Miemiec, K. Sawicka, Prawo finansów publicznych sektora samorzq̨dowego, Wyd. Wolters Kluwer, Warszawa 2013.

Tyniewicki M., Wieloletnia prognoza finansowa jako podstawa gospodarki finansowej jednostki samorzqdu terytorialnego, [w:] P. Borszowski, J. M. Salachna, K. Stelmaszczyk (red.), Prawo i Administracja dla Regionu. Zagadnienia prawnofinansowe, Wyd. PWSZ, Wałbrzych 2016.

Ustawa z dnia 7 października 1992 r. o Regionalnych Izbach Rachunkowych (t.j. Dz.U. z 2018 r., poz. 2500).

Ustawa z dnia 27 sierpnia 2009 r. o finansach publicznych (t.j. Dz.U. z 2019 r., poz. 869).

Ustawa z dnia 14 grudnia 2018 r. o zmianie ustawy o finansach publicznych oraz niektórych innych ustaw (Dz.U. z 2018 r., poz. 2500).

Uzasadnienie do rządowego projektu ustawy o finansach publicznych, druk sejmowy nr 1181 z dnia 20 października 2008 r., http://orka.sejm.gov.pl /Druki6ka.nsf/wgdruku/1181 [dostęp: 22-02-2019].

Uzasadnienie do rządowego projektu ustawy o zmianie ustawy o finansach publicznych oraz niektórych innych ustaw, druk sejmowy nr 2787 z dnia 17 lipca 2018 r. http://www.sejm.gov.pl/Sejm8.nsf/druk.xsp?nr=2787 [dostęp: 25-02-2019].

Rozporządzenie Ministra Finansów z dnia 10 stycznia 2013 r. w sprawie wieloletniej prognozy finansowej jednostki samorządu terytorialnego (Dz.U. z 2013 r. poz. 86).

Wiśniewski M., Dług samorzq̨dowy i jego limity w świetle wieloletnich prognoz finansowych jednostek samorządu terytorialnego w Polsce, „Finanse Komunalne" 2014, nr 4.

Wiśniewski M., Planowanie finansowe w zarządzaniu długiem samorządowym - analiza dynamiczna na przykładzie województw samorządowych, „Kwartalnik Kolegium Ekonomiczno-Społecznego Studia i Prace. Szkoła Główna Handlowa" 2016, nr 2. 